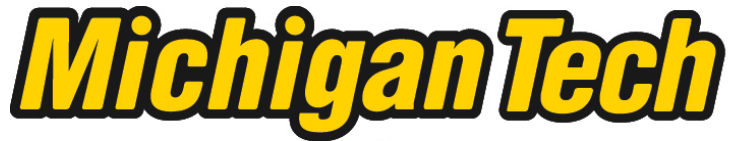 \\ Michigan Technological University Create the Future Digital Commons @ Michigan Tech
}

Dissertations, Master's Theses and Master's Reports - Open

Dissertations, Master's Theses and Master's

Reports

2011

\section{Assessing visual disturbance conditions on the Custer National Forest}

Scott B. Robinson

Michigan Technological University

Follow this and additional works at: https://digitalcommons.mtu.edu/etds

Part of the Forest Sciences Commons

Copyright 2011 Scott B. Robinson

\section{Recommended Citation}

Robinson, Scott B., "Assessing visual disturbance conditions on the Custer National Forest", Master's Thesis, Michigan Technological University, 2011.

https://doi.org/10.37099/mtu.dc.etds/150

Follow this and additional works at: https://digitalcommons.mtu.edu/etds

8 Part of the Forest Sciences Commons 


\title{
ASSESSING VISUAL DISTURBANCE CONDITIONS ON THE CUSTER
} NATIONAL FOREST

\author{
By \\ Scott B. Robinson

\begin{abstract}
A THESIS
Submitted in partial fulfillment of the requirements for the degree of MASTER OF SCIENCE FOREST ECOLOGY AND MANAGEMENT
\end{abstract} \\ MICHIGAN TECHNOLOGICAL UNIVERSITY \\ 2011
}

(C) 2011 Scott B. Robinson 
This thesis, “Assessing Visual Disturbance Conditions on the Custer National Forest," is hereby approved in partial fulfillment of the requirements for the Degree of MASTER OF SCIENCE IN FOREST ECOLOGY AND MANGEMENT.

School of Forest Resources and Environmental Science

Signatures:

Thesis Advisor

Dr. Martin F. Jurgensen

Dean

Dr. Margaret R. Gale

Date 


\section{Table of Contents}

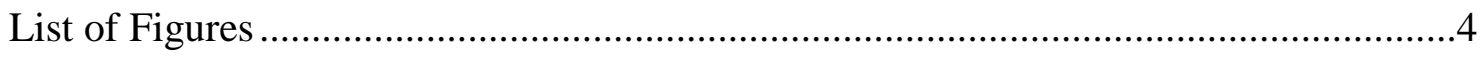

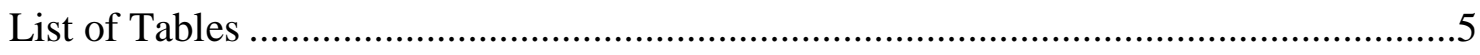

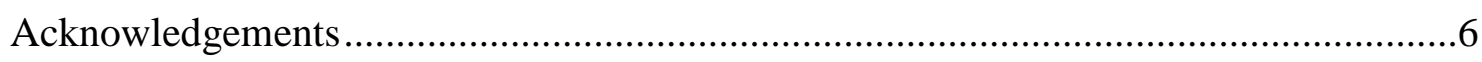

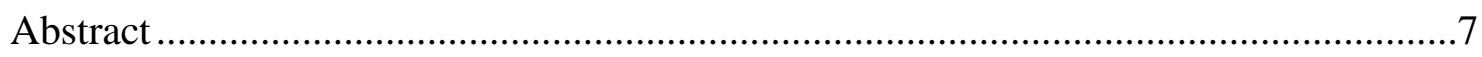

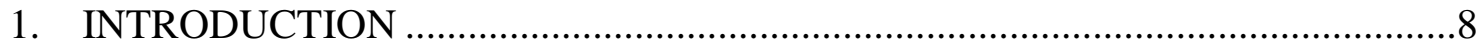

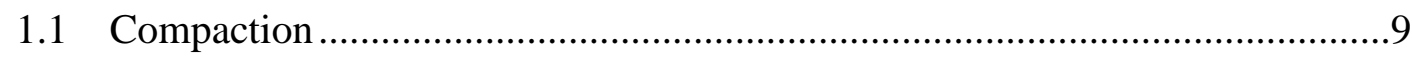

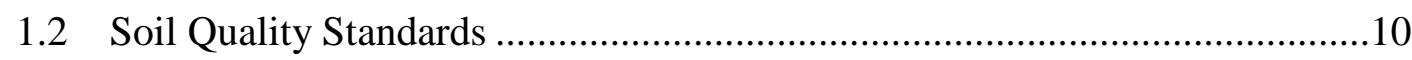

1.3 U.S. Forest Service Forest Soil Disturbance Monitoring Protocol .................11

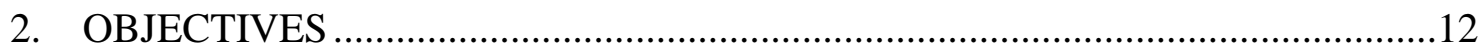

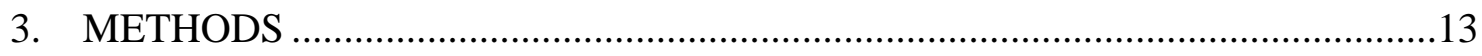

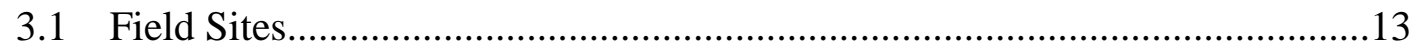

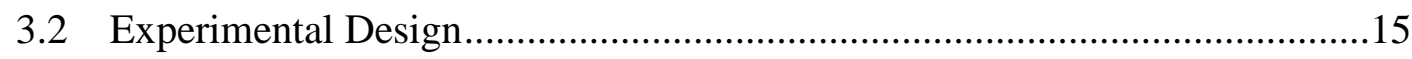

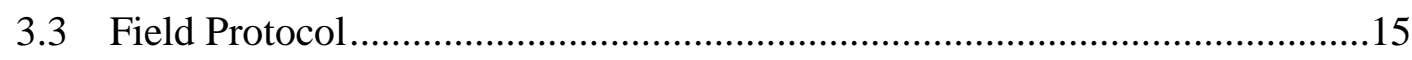

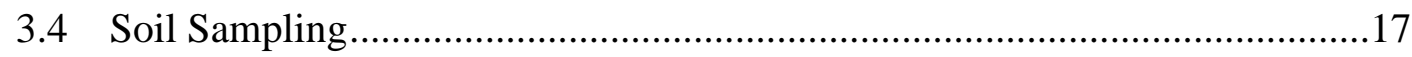

3.5 Laboratory Methods.......................................................................... 18

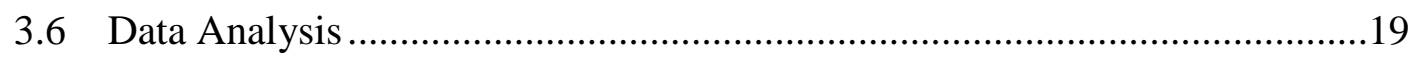

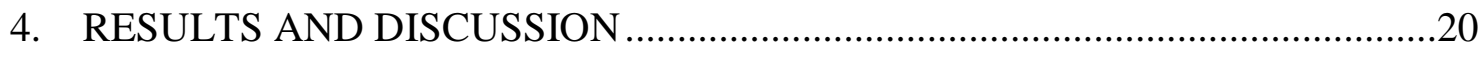

4.1 Soil Physical Properties .......................................................................20

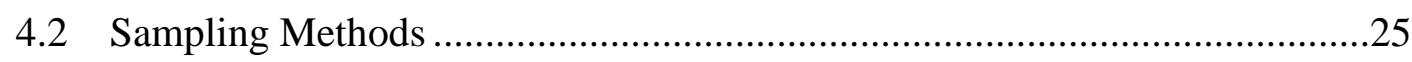

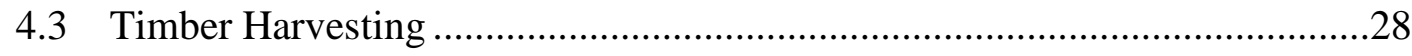

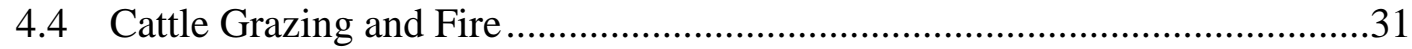

4.5 Bulk Density - Disturbance Class Relationships ........................................33

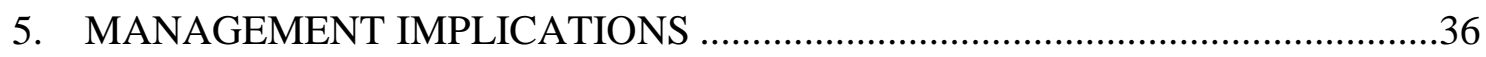

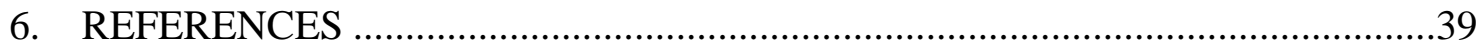

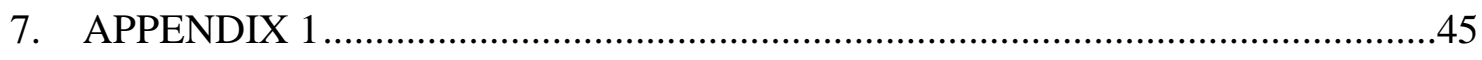

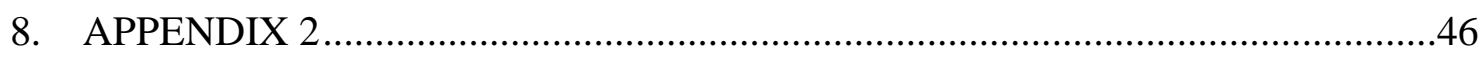

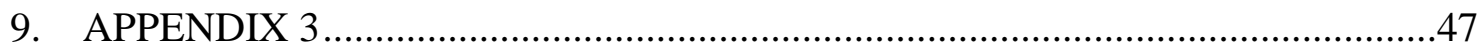




\section{List of Figures}

Figure 3.1 Map of the Custer National Forest .....................................................14

Figure 3.2 Random transect sampling diagrams: A 2009 and B 2010 ......................17

Figure 4.1 Average percent fines (silt and clay combined) for FSDMP Disturbance Class 0 by silvicultural prescription for initial stand conditions (undisturbed) prior to timber harvesting

Figure 4.2 Average percent organic matter for FSDMP Disturbance Class 0 by soil depth across all stand for initial stand conditions (undisturbed) prior to timber harvesting

Figure 4.3 Average fine fraction bulk density values for FSDMP Disturbance Class 0 by depth across all stands for initial stand conditions (undisturbed) prior to timber harvesting

Figure 4.4 Impact of timber harvesting prescription on the areal extent of soil disturbance from year 2 transect data: A) 0-5 years since harvest, and B) 6 10 years since harvest

Figure 4.5 Combined areal extent of soil disturbance from timber harvesting, cattle grazing, and fire from year 2 transect data: A) 0-5 years since harvesting, and B) 6-10 years since timber harvesting.

Figure 4.6 Fine fraction bulk density values and their associated FSDMP visual disturbance class from both years' data for the commercial thinning silvicultural prescription 


\section{List of Tables}

Table 3.1 Physical site characteristics for the Ashland Ranger District

Table 4.1 Initial stand soil physical attributes from FSDMP disturbance class 0 bulk density data for all sivlicultural prescriptions

Table 4.2 Areal extent of soil disturbance after harvesting on the Custer National Forest, as estimated by the FSDMP and the Revised Transect sampling methods.

Table 7.1 Abbreviated FSDMP soil attribute monitoring form. Except for forest floor depth, 1's (present) or 0's (absent) are used to indicate soil cover and impacts to the mineral soil

Table 8.1 Total number of timber harvesting related disturbances per FSDMP disturbance class for prescriptions $0-5$ years combined with represented soil series

Table 9.1 Total number of timber harvesting related disturbances per FSDMP disturbance class for prescriptions 6 - 10 years combined with represented

soil series 


\section{Acknowledgements}

I would like to thank my advisor Marty Jurgensen for all his help in all aspects of this project. I would also like to thank him for all his help outside of the classroom over the past 2 years as well. In general, I would like to thank my committee members for all their input with this project. I would specifically like to thank Jim Pickens for his help with all the statistical analysis, because I couldn’t have done it without him. I would like to thank Debbie Page-Dumroese for her help in the field and her input in most aspects of this project. I would also like to thank Dave Chesney for being the brave outside committee member, and volunteering to be a soil scientist rather than a Chemist for a couple of days. Thanks to John Lane for his input and oversight over the past two field seasons, and thanks to him and the Custer National Forest for the opportunity to be involved with this project. Last but not least, I would like to thank Josh Kelly for all his help in the field, lab, and with GIS over the past two years. Thanks all. 


\section{Abstract}

Assessment of soil disturbance on the Custer National Forest was conducted during two summers to determine if the U.S. Forest Service Forest Soil Disturbance Monitoring Protocol (FSDMP) was able to distinguish post-harvest soil conditions in a chronological sequence of sites harvested using different ground-based logging systems. Results from the first year of sampling suggested that the FSDMP point sampling method may not be sensitive enough to measure post-harvest disturbance in stands with low levels of disturbance. Therefore, a revised random transect method was used during the second sampling season to determine the actual extent of soil disturbance in these cutting units. Using combined data collected from both summers I detected statistically significant differences $(\mathrm{p}<0.05)$ in fine fraction bulk density measurements between FSDMP disturbance classes across all sites. Disturbance class 3 (most severe) had the highest reported bulk density, which suggest that the FSDMP visual class estimates are defined adequately allowing for correlations to be made between visual disturbance and actual soil physical characteristics.

Forest site productivity can be defined by its ability to retain carbon and convert it to above- and belowground biomass. However, forest management activities that alter basic site characteristics have the potential to alter productivity. Soil compaction is one critical management impact that is important to understand; compaction has been shown to impede the root growth potential of plants, reduce water infiltration rates increasing erosion potential, and alter plant available water and nutrients, depending on soil texture. A new method to assess ground cover, erosion, and other soil disturbances was recently published by the U.S. Forest Service, as the Forest Soil Disturbance Protocol (FSDMP). The FSDMP allows soil scientists to visually assign a disturbance class estimate (0 none, 1, 2, 3 - severe) from field measures of consistently defined soil disturbance indicators (erosion, fire, rutting, compaction, and platy/massive/puddled structure) in small circular $(15 \mathrm{~cm})$ plots to compare soil quality properties pre- and post- harvest condition. Using this protocol we were able to determine that ground-based timber harvesting activities occurring on the Custer National Forest are not reaching the 15\% maximum threshold for detrimental soil disturbance outlined by the Region 1 Soil Quality Standards. 


\section{INTRODUCTION}

It is common practice for forest managers to base their harvest decisions on maintaining sustainable forests and long-term forest productivity (Burger et al. 2010). Basic requirements for sustainable land management are that the impacts of management operations do not exceed the time it takes sites to recover their natural capacity before harvesting again. Sustainable forestry management is economically viable, environmentally sound, and is socially acceptable (Worrell and Hampson 1997; Sample et al. 2006; Burger et al. 2010). While many terms and definitions exist for what a sustainable forest is, maintenance of soil productivity is a key element that promotes long-term ecosystem function (Powers et al. 1998; Page-Dumroese et al. 2000). Soil quality, an integral component of soil productivity, can be defined as a soil's ability to support vegetative growth, and if not modified, soils have a natural productive potential based on genesis and landscape position (Power and Meyers 1989; Page-Dumroese et al. 2000; Burger et al. 2010). Therefore, soil quality is intrinsically tied to the condition of the current soil physical, chemical, and biological properties and includes measures of bulk density, porosity, texture, available water holding capacity, soil organic matter, and cation exchange capacity (CEC). Consequently, forest vegetation management treatments have the ability to alter soil quality by compaction, erosion, displacement, and organic matter removal (which can alter nutrient availability). These impacts can also occur in a complex fashion, varying from beneficial to harmful, with the latter seemingly more common (Kozlowski 1999), but often the impacts are dependent on climatic regime and soil texture (Page-Dumroese et al. 2006). 


\section{Compaction}

Soil compaction has long been understood as the primary form of soil disturbance associated with ground-based timber harvesting operations (Hatchell et al. 1970;

Reisinger and Simmons 1988; Williamson and Nielson 2000), and a change in compaction is one of the most visually noticeable traits for post-harvest soil assessments. Compaction of forest soils results from energy exerted on the soil from applied loads, vibrations, and ground pressure caused by heavy machine traffic associated with timber harvesting and site preparation (Murphy 1982; Steber et al. 2007; Johnson et al. 2007). Soil compaction has been shown to decrease total porosity, which increases soil bulk density and soil strength (Greacan and Sands 1980). However, the degree of compaction from timber harvesting and site preparation and its impact on site sustainability or productivity is dependent upon specific internal soil physical properties (e.g. texture, organic matter, particle size and volumetric water content) during the time of the disturbance (Howard et al. 1981; Bock and VanRees 2002; Page-Dumroese et al. 2006). Soil compaction reduces water infiltration rates by decreasing hydraulic conductivity, which can increase soil erosion and alter landscape hydrology function (Harr et al. 1979). Soil compaction studies show mixed results on vegetative production. Studies indicate: 1) reduced plant productivity from impeded root growth, water infiltration, and gas and nutrient exchange (Froelich et al. 1986; Helms and Hipkin 1986; Kabzems and Haeussler 2005), 2) no change in plant productivity (Miller et al. 1996), or 3) increased plant growth from greater water availability and nutrient uptake (Gomez et al. 2002). Consequently, the soil plant growth relationship to compaction is complex, and is 
determined by interactions between site-specific soil properties and the different physiological processes of plants (Siegel-Issem et al. 2005).

\section{Soil Quality Standards}

Public land managers in the USA are required to maintain the productive capacity of soils by numerous laws, including the Multiple Use Sustained Yield Act of 1960, the Forest and Rangeland Renewable Resources Planning Act of 1974, and the National Forest Management Act of 1976 (Page-Dumroese et al. 2000). In response to these mandates, the U.S. Forest Service was one of the earliest agencies to develop soil quality standards and guidelines to help promote sustainable forest management by mitigating potential risks that could reduce forest productivity following timber harvesting and site preparation (Page-Dumroese et al. 2006; Neary et al. 2010). Although soil quality standards and guidelines vary for each of the Forest Service Regions, soil monitoring measurements can generally be split into two different categories: (1) disturbance indicators (i.e. compaction, rutting, displacement, severely burned, surface erosion, organic matter loss, mass movement, puddling, ground cover, and altered wetness), and (2) soil quality indicators such as soil stability, hydrology, nutrient cycling, productivity, and buffering capacity (USDA Forest Service 1991). Currently, individual forests with uniquely different soil characteristics and local climates are applying these general regional guidelines as monitoring standards, often using their own methods and monitoring protocols that cannot be defended statistically. In addition, disparate methods do not allow for data sharing across similar landscapes. Improved consistency, common definitions, and statistical robustness in a monitoring effort based on pre- and post- 
management disturbance levels would increase the reliability of the data for inclusion in a national soil disturbance database (Burger 1997; Page-Dumroese et al. 2000; Curran et al. 2005; DeLuca and Archer 2009).

\section{U.S. Forest Service Forest Soil Disturbance Monitoring Protocol}

The U.S. Forest Service Forest Soil Disturbance Monitoring Protocol (FSDMP) has become an important tool used by numerous forest specialists conducting soil monitoring and assessment surveys both pre- and post- management activity (PageDumroese et al. 2009a, b). This protocol establishes a standard inventory, monitoring, and assessment tool that are consistent and unambiguous for soil scientists to use across all U.S. Forest Service National Forests. The FSDMP was designed to be flexible enough to collect information on a variety of forest management activities across the full range of soil types. In this protocol, soil disturbance is assessed by recording the presence or absence ( 1 - present, 0 - not) of seven selected soil disturbance attributes (forest floor impacted, topsoil displacement, erosion, rutting, burning, compaction, platy/massive/puddle structure), which provides an estimate of both the extent and depth of the disturbances. By employing common terms and uniform guidelines, the FSDMP allows data to be interpreted consistently and are linked to current Regional Soil Quality Standards and Guidelines (Neary et al. 2010; Davis et al. 2010).

The goal of the FSDMP is to be a rapid assessment tool that obtains representative estimates of the amount and types of disturbances caused from management activities. Like other soil assessment protocols it uses visual criteria to assess soil disturbance following timber harvesting. In the past, visual soil assessment with the Weyerhaeuser 
protocol (Heninger et al. 2002) and in Region 6, U.S. Forest Service (Howes et al. 1983) often overestimated the percentage of “detrimental disturbance” in cutting units based on regional soil-quality numerical standards (e.g., a 15\% increase above the undisturbed bulk density) (Miller et al. 2010). Unlike these other protocols the FSDMP does not define any visual disturbance class as “detrimental disturbance” because the impacts of soil disturbance on site productivity vary by soil type (Page-Dumroese 2009b).

Currently, no assessments of the FSDMP have been done to determine its' usefulness in (1) assessing post-harvested sites in a chronological sequence, and (2) evaluating changes in soil physical properties after various logging practices on the soil types specific to the Ashland Ranger District of the Custer National Forest.

\section{OBJECTIVES}

The objectives of my study are to determine: (1) if silvicultural prescription (seed tree, shelterwood, and commercial thinning) produces similar levels of post-harvest soil disturbance levels, (2) if the time since timber harvesting is an important process in restoring sites to lower levels of detectable soil disturbance, and (3) if soil bulk density can be used to quantify differences in soil disturbance visual classes from the FSDMP. 


\section{METHODS}

\section{Field Sites}

My study was conducted on the Custer National Forest in southeastern Montana. Primary data collection occurred on the Ashland Ranger District, which has active timber harvesting and cattle grazing programs (Figure 3.1). Ponderosa pine (Pinus ponderosa C. Lawson var. scopulorum Engelm.) is the dominant forest type, which occurs interspersed with steppe and shrub-steppe habitat types within the northern Great Plains grassland biome (Hansen and Hoffman 1988). The dominant soil on the Ashland Ranger District is the Cabba Association, which is comprised of the Cabba, and Midway soil series (Table 1). The Cabba soil series is classified as a loamy, mixed, superactive, calcareous, frigid, shallow Typic Ustorthents, and the Midway soil series is classified as a clayey, smectitic, calcareous, mesic, shallow Ustic Torriorthents (USDA Soil Conservation Service 1971).

Other soils on the Ashland Ranger District found in conjunction with the Cabba Association are not dominated by one soil association, but are related to slope changes. There are six distinct soil series that occur on slopes encompassed by this study, which range from $0-75 \%$ (Table 3.1). The Farland soil series is classified as a fine-silty, mixed, superactive, frigid Typic Argiustolls; the Havrelon soil series is a fine-loamy, mixed, superactive, calcareous, frigid Typic Ustifluvents; the Campspass soil series is a fine, smectitic, frigid Typic Haplustalfs; the Barvon soil series is classified as a fineloamy, mixed, superactive, frigid Entic Haplustolls; the Rapelje soil series is classified as a fine-silty, mixed, superactive, frigid Aridic Glossic Natrustalfs; and lastly the Heldt soil series is classified as a fine, smectitic, mesic Ustertic Haplocambids (USDA Soil Conservation Service 1971). All Ashland Ranger District soils are derived from 
Paleocene continental deposits, including stream-deposited sediments, as well as weathering of the sandstone and siltstone bedrock/parent material (Hansen and Hoffman 1988).

Table 3.1

Physical site characteristics for the Ashland Ranger District.

\begin{tabular}{cccc}
\hline Soil Association & Soil Series & Slope (\%) & $\begin{array}{c}\text { Surface Soil } \\
\text { Texture }\end{array}$ \\
\hline Cabba & Cabba & $15-50$ & Silt Loam \\
& Midway & $15-50$ & Clay Loam \\
\hline & Farland & $0-20$ & Silt Loam \\
& Havrelon & $0-6$ & Silt Loam \\
& Campspass & $3-15$ & Loam \\
& Barvon & $2-70$ & Loam \\
& Rapelje & $1-15$ & Silt Loam \\
& Heldt & $0-25$ & Sandy Clay Loam \\
\hline
\end{tabular}

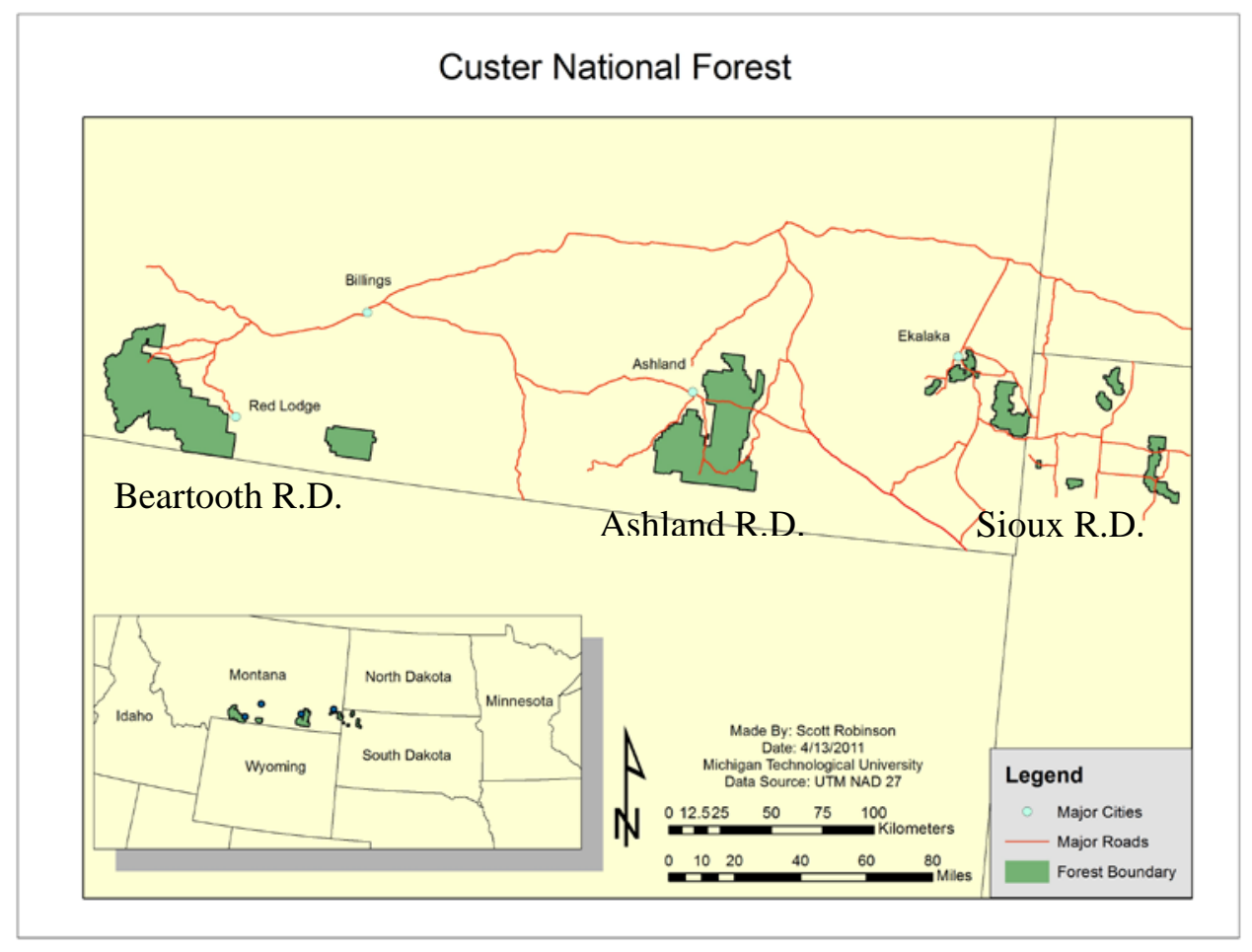

Figure 3.1. Map of the Custer National Forest. 


\section{Experimental Design}

The sampling design outlined by the FSDMP was used in this study (PageDumroese et al. 2009a) in which random transects are established within a harvest area. Total number of sample points in each harvest area is calculated on-site and is dependent on the variability of each of the soil disturbance attributes. Sampling units were originally grouped into 2 or 3 replicates, based on the six following criteria: (1) time since harvest, (2) silvicultural prescription, (3) texture, (4) aspect, (5) slope, and (6) unit size. However, due to the irregular size of the cutting units, the dissected nature of the landscape, and similarities in vegetation across all sites in the study area, units were replicated using three criteria: (1) time since harvest, (2) silvicultural prescription (harvest intensity), and (3) texture. The final design consisted of 2 or 3 cutting units for each silvilcultural prescription (seed tree, shelterwood, and commercial thinning), which were grouped by age (0-5 and 6-10 years) since timber harvesting occurred, and one undisturbed control replicate (3 stands) that covered the range of potential soil textures for a total of 21 sampling sites.

\section{Field Protocol}

\section{$\underline{\text { Season \#1 (2009) }}$}

Field methods for data collection used the random transect option of the FSDMP (Page-Dumroese et al. 2009a and b). A random start point was chosen within the harvest unit, and a transect of at least 30 sample points was established (Figure $3.2 \mathrm{~A}$ ). This first transect covered the entire harvest unit so that an adequate assessment of soil variability within the entire cutting unit was achieved. At each sample point the condition of the 
forest floor was evaluated, followed by digging a soil pit $>30 \mathrm{~cm}$ to assess the current condition of the mineral soil by identifying visual indicators listed in the FSDMP (i.e. rutting, compaction, platy/massive/puddled structure) see Appendix 1 for the complete list and FSDMP sampling form. A disturbance class number was assigned for each indicator, based on the extent and depth of the disturbance: 0 - (none), 1, - 2, - or 3 (low to high - severity). Year 1 sample size within a harvest unit was determined by variability of each visual disturbance attribute, and combined with an $80 \%$ confidence interval. However, a minimum of 30 sampling points were used when the variability of the soil disturbance attributes found within a unit was negligible.

\section{$\underline{\text { Season \#2 (2010) }}$}

The previous field season sampling resulted in an uneven distribution of soil disturbance classes, so a second field season was necessary to obtain additional disturbance class estimates (Figure 3.2 B). An analog to the FSDMP was used to collect Season 2 data. This method used random transects to sample for soil disturbance within cutting units, however when a soil impact was found along the transect, it was measured from the beginning of the impact to the end of where it intersected the transect. The percent of each disturbance along the transect was calculated. A random number generator was then used to determine where a sample point would be placed within the disturbance. This sample point was used to assess current soil conditions using the FSDMP rapid assessment guidelines, as done in 2009 (Page-Dumroese et al. 2009 a). Each soil disturbance along the transect was visually classified (0 - none, 1, 2, and 3, low - high severity) and measured providing an estimate of the amounts of disturbance 
present by disturbance class within a cutting unit (\% disturbed by disturbance class). The sum of the disturbance lengths (\% disturbed) for each disturbance class present provided a total estimate of the areal extent of soil disturbance within a unit. This method increased and balanced the sample sizes of the higher disturbance classes (1-3) by focusing on the disturbances rather than on random sample points used in 2009.

\section{$\underline{\mathrm{A}}$}

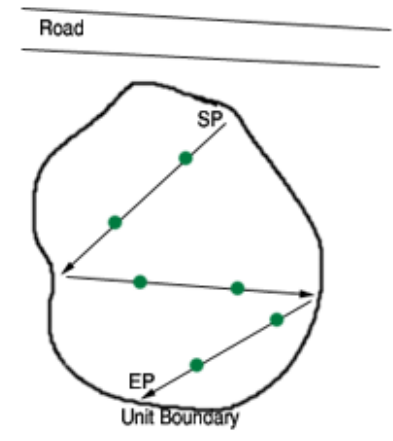

B

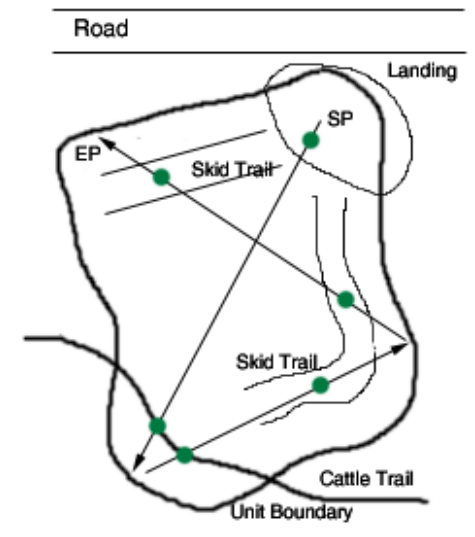

Figure 3.2. Random transect sampling diagrams: A 2009 and B 2010.

\section{Soil Sampling}

For each sample season and in each cutting unit, three soil core sub samples were taken with a hand-driven soil corer $\left(5 \mathrm{~cm}\right.$ diameter - volume of $\left.90 \mathrm{~cm}^{3}\right)$ in each disturbance class found in that unit. The soil cores were separated into 2 depths $(0-10 \mathrm{~cm}$ and 10-20 cm), so potentially 24 soil cores could be taken per unit (4 soil disturbance categories x 3 subsamples x 2 soil depths). A total of 182 soil samples were collected 
during the 2009 field season, with an additional 424 soil samples taken during the 2010 field season, giving a project total of 606 soil samples.

\section{Laboratory Methods}

Each soil core was weighed and then dried at $105^{\circ} \mathrm{C}$ for 24 hours, weighed again to determine the cores oven-dry weight, sieved through a $2 \mathrm{~mm}$ mesh screen, and the weights of both the fine fraction $(<2 \mathrm{~mm})$ sample and rock-fragments were determined. Fine fraction soil bulk density ( $\rho_{\mathrm{bs}}$ ) was calculated from the following formula:

$$
\rho_{\mathrm{bs}}=\rho_{\mathrm{bT}}\left(1-\mathrm{g}_{\mathrm{r}}\right) /\left(1-\mathrm{V}_{\mathrm{r}}\right) \quad \text { (Page-Dumroese et al. 1999) }
$$

where $\mathrm{g}_{\mathrm{r}}$ (gravimetric rock-fragment content) was calculated by dividing the mass of the rock fragments by the total sample mass. $\mathrm{V}_{\mathrm{r}}$ (volumetric rock-fragment content) was derived from the following equation:

$$
\mathrm{V}_{\mathrm{r}}=\rho_{\mathrm{bT}}\left(\mathrm{g}_{\mathrm{r}} / \rho_{\mathrm{br}}\right)
$$

where rock-fragment density ( $\rho_{\mathrm{br}}$ ) will be assumed to be $2.65 \mathrm{Mg} / \mathrm{m}^{3}$, which is the average of rock minerals commonly found in soils (Federer et al. 1993), and $\rho_{\mathrm{bT}}$ is total bulk density. Bulk density and rock content measurements were used to convert the fine earth fraction of the soil $(<2 \mathrm{~mm})$ to a mass-per-unit basis. Soil organic matter was determined by loss-on-ignition at $500^{\circ} \mathrm{C}$ for 4 hours (Santisteban et al. 2004). Soil texture was measured using the hydrometer method (ATSM 1986). 


\section{Data Analysis}

An analysis of variance (ANOVA) procedure was performed on the year 2 transect data with SAS software (Version 9.2) to determine if statistical differences existed between silvicultural prescriptions and time. The statistical parameters of the FSDMP used in my study were set at an 80\% confidence level and a 10\% (+/-5\%) confidence interval. In order to compare year 1 FSDMP data and year 2 transect data, 80\% confidence intervals were also determined for the transect sampling method. Tests for significant differences in mean unit disturbance (sum of avg \% transect disturbed) by disturbance class (1, 2, and 3), time since harvest (0-5 and 6-10 years), and prescription (seed tree, shelterwood, and commercial thinning) were performed using the StudentNewman-Keul multiple range test on the Ashland Ranger District soil data.

Analysis of year 1 stand level soil bulk density was done with a regression model that used organic matter and percent fines (amount silt and clay) as predictors of fine fraction soil bulk density by sampling depth $(0-10 \mathrm{~cm}$ and $10-20 \mathrm{~cm})$; sampling depth was represented in the regression model as a dummy variable. Type III sums of squares were used to determine the contribution of each independent variable after all other variables were included in the linear model. The probabilities ( $\mathrm{p}$ - values) for each independent variable were used to determine if: 1) differences exist between fine fraction bulk density, texture (percent fines), organic matter, and depth across disturbance class 0 samples (used as pre-harvest stand physical condition estimates) for each of the prescriptions, and 2) significant differences in fine fraction bulk density values were present among age class, prescription, depth, and disturbance class estimates postharvest. 


\section{RESULTS AND DISCUSSION}

\section{Soil Physical Properties}

As with most stands in the Ashland Ranger District, the control stands had been selectively logged many years before, however no legacy soil disturbances were found during a walk-through of each stand. Therefore, we assumed that any soil impacts had recovered to pre-disturbance levels. The Cabba soil association is the most dominant soil on the Ashland Ranger District and consists of two fine-textured soils, the Cabba (silt loam) and Midway (clay loam) soil series. For this study I used percent silt and clay (percent fines) as a surrogate measure of soil texture. Wet soils or soils with high amounts of silt and clay particles (fine-textured) can be more readily compacted during timber harvesting as compared to dry or coarse-textured forest soils (Williamson and Neilsen 2000; Tables 3.1 and 4.1).

Additionally, soils with high amounts of fine particles (> $20 \%$ clay and $>40 \%$ silt, or $>50 \%$ combined) can contain higher amounts of organic matter. Mineral soils with high amounts of organic matter generally have larger, stronger, more stable soil aggregates which help soils resist compaction (Clayden and Hollis 1984; Dexter 2004; Soane 1990). However, in a review of machine traffic on physical soil properties of ash-cap soils (similar properties to silt loam - Cabba Association), Johnson et al. (2007) shows that when these soils have increased moisture conditions they become very susceptible to substantial disturbance from timber harvesting, and may not recover from the disturbed condition for years. Because of the contradiction in literature on the relationship of soil fines and organic matter, we show the range of conditions of 
disturbance class 0 for each age-class, silvicultural prescription, and soil depth (Table 4.1).

Table 4.1

Initial stand soil physical attributes from FSDMP disturbance class 0 bulk density data for all sivlicultural prescriptions.

\begin{tabular}{cccccc}
\hline Prescription & $\begin{array}{c}\text { Age } \\
\text { (yrs) }\end{array}$ & $\begin{array}{c}\text { Depth } \\
\text { (cm) }\end{array}$ & $\begin{array}{c}\text { OM } \\
\text { (\%) }\end{array}$ & $\begin{array}{c}\text { Fines } \\
\text { (\%) }\end{array}$ & $\begin{array}{c}\text { Rock } \\
\text { (\%) }\end{array}$ \\
\hline Commercial Thin & $0-5$ & $0-10$ & 4.78 & 38.27 & 0.7 \\
Commercial Thin & $0-5$ & $10-20$ & 4.28 & 35.67 & 1.42 \\
Commercial Thin & $6-10$ & $0-10$ & 8.86 & 52.63 & 1.71 \\
Commercial Thin & $6-10$ & $10-20$ & 6.62 & 55.73 & 2.06 \\
Shelterwood & $0-5$ & $0-10$ & 6.57 & 69.16 & 0.27 \\
Shelterwood & $0-5$ & $10-20$ & 4.64 & 70.27 & 1.79 \\
Shelterwood & $6-10$ & $0-10$ & 9.02 & 51.58 & 2.49 \\
Shelterwood & $6-10$ & $10-20$ & 5.69 & 53.27 & 3.36 \\
Seed Tree & $0-5$ & $0-10$ & 7.09 & 62.71 & 2.48 \\
Seed Tree & $0-5$ & $10-20$ & 6.19 & 65.91 & 6.41 \\
Seed Tree & $6-10$ & $0-10$ & 7.22 & 64.00 & 6.14 \\
Seed Tree & $6-10$ & $10-20$ & 4.94 & 66.93 & 4.38 \\
Control & Uncut & $0-10$ & 7.28 & 58.31 & 1.43 \\
Control & Uncut & $10-20$ & 6.01 & 59.73 & 0.48 \\
\hline
\end{tabular}

${ }^{1}$ Fines consist of clay and silt-sized particles.

Of all the silvicultural prescriptions evaluated, commercial thinning had the lowest amount of fine-textured soil and these levels were statistically different from the other prescription types, including the uncut control (Figure 4.1). Ampoorter et al. (2007) show that dry sandy soils lack cohesion or structure and are more susceptible to shear forces caused from timber harvesting equipment. However, there are no significant differences in percent fines between soil sampling depths $(0-10 \mathrm{~cm}$ and $10-20 \mathrm{~cm}$; data not shown). 


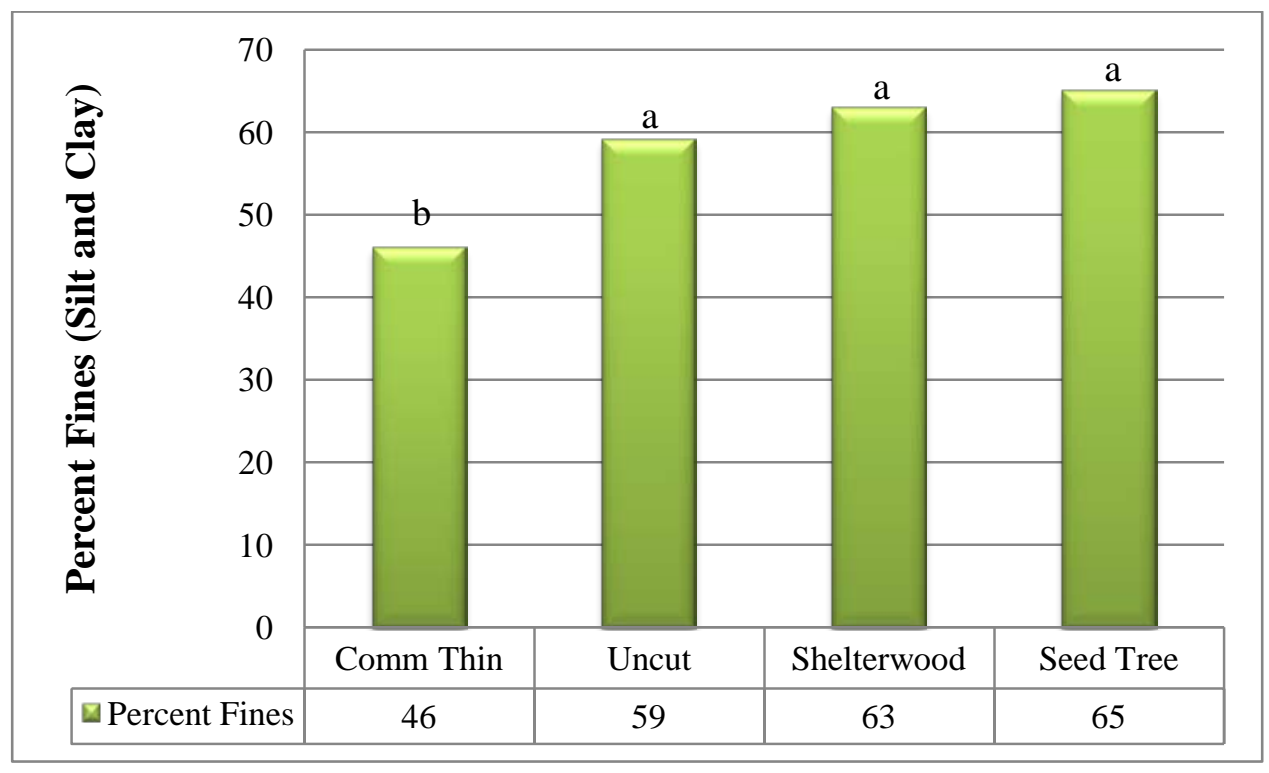

Figure 4.1. Average percent fines (silt and clay combined) for FSDMP Disturbance Class 0 by silvicultural prescription for initial stand conditions (undisturbed) prior to timber harvesting. Different letters among silvicultural prescriptions indicates statistically significant differences $(\mathrm{p}<0.05)$.

In contrast to percent fines no significant statistical organic matter differences were detected between each silvicultural prescription and the uncut control, but there were significant differences in organic matter by soil depth. The 0-10 cm soil depth had statistically significant greater amounts of organic matter present than the $10-20 \mathrm{~cm}$ sampling depth (Figure 4.2). Although soil mixing during timber harvesting alters the amount of surface organic matter, low-impact harvest operations can increase surface organic matter and fuels (Adams 1973). However, surface organic matter movement into the mineral soil is governed by bioturbation, temperature, and moisture regime (Spears et al. 2003; Busse 1994). 


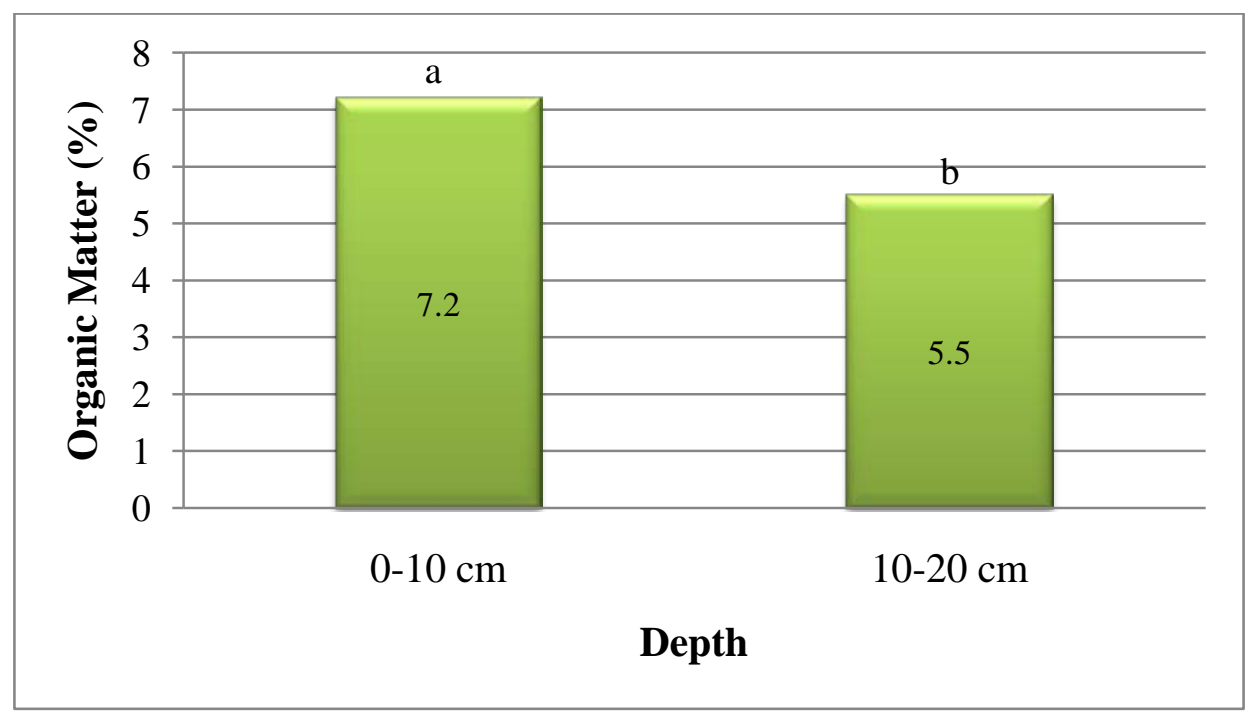

Figure 4.2. Average percent organic matter for FSDMP Disturbance Class 0 by soil depth across all stands for initial stand conditions (undisturbed) prior to timber harvesting. Different letters among soil depths indicates statistically significant differences $(p<0.05)$.

Mineral soil bulk density is inversely related to the amount of fine particles and organic matter; these soil physical characteristics increase as bulk density decreases (Dexter 2004). For this reason a regression analysis was used to predict differences in pre-treatment bulk densities between prescriptions using the FSDMP disturbance class 0 bulk density samples. When only one predictor variable was used, both percent fines (p $=0.0028)$ and organic matter $(\mathrm{p}<0.0001)$ were highly statistically significant predictors of bulk density (data not shown). However, when both predictor variables are present in the model, organic matter content is the only statistically significant predictor of fine fraction soil bulk density ( $\mathrm{p}<0.0001$ ), while percent fines is not near statistical significance with $\alpha=0.05(\mathrm{p}=0.38)$. Pre-treatment initial fine fraction soil bulk density (FBD) can be estimated from the following equation FBD $=1.51+-2.64 *(\% \mathrm{OM})\left(\mathrm{R}^{2}\right.$ $=0.23)$. These two predictor variables are relatively highly correlated $(r=0.40)$, 
however organic matter content explains much more of the variability that percent fines does not when estimating mineral soil fine fraction bulk density on the Ashland Ranger Distinct of the Custer National Forest.

FSDMP disturbance class 0 fine fraction bulk densities were statistically different between the two soil sampling depths $(0-10 \mathrm{~cm}$ and $10-20 \mathrm{~cm})$ (Figure 4.3). This is similar to other studies that show increasing soil bulk density with depth as a result of natural compaction and lower amounts of organic matter (Kozlowski 1999; Adams 1973). However, no statistical differences in soil bulk density were found among the silvicultural prescriptions and the uncut control for FSDMP disturbance class 0's (data not shown). This lack of statistical difference among FSDMP Disturbance Class 0's across all the silvicultural prescriptions indicates that (1) soil differences are relatively minor across all sampled units and (2) the FSDMP class descriptors can be used to define 'no disturbance' sample points. Overall, using the FSDMP disturbance class 0 estimates as "post hoc' estimates of pre-harvest soil conditions is justified, and any change in fine fraction bulk density in the higher disturbance classes can be attributed to timber harvesting operations. 


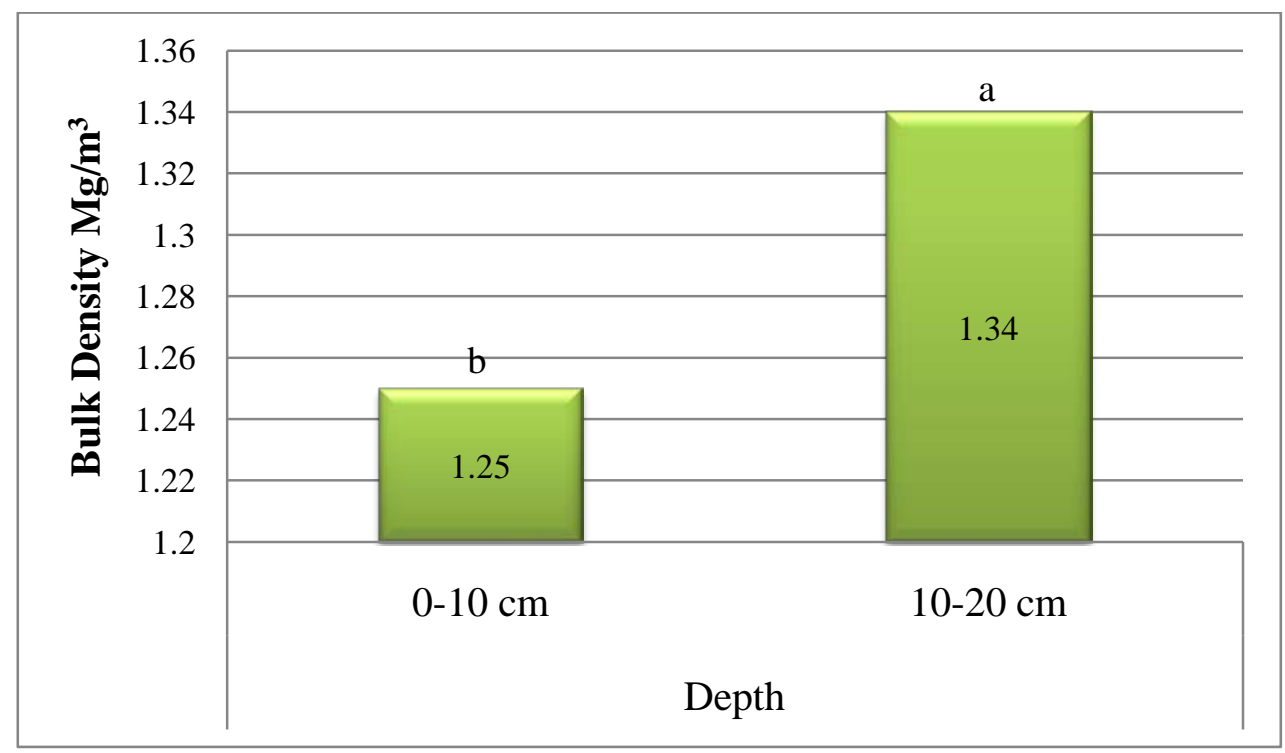

Figure 4.3. Average fine fraction bulk density values for FSDMP Disturbance Class 0 by depth across all stands for initial stand conditions (undisturbed) prior to timber harvesting. Different letters among soil depths indicates statistically significant differences $(\mathrm{p}<0.05)$.

\section{Sampling Methods}

Areal extent of soil disturbance is defined as the percent of each disturbance class recorded as a fraction of the total number of points collected throughout each harvest unit. The areal extent of soil disturbance by disturbance class was determined in year 2 by treating the length (\% disturbed by disturbance class) of a transect as the observation. The sum of these observations provided an estimate for the total areal soil disturbance by unit. Unit soil disturbance areal extents using the FSDMP were based on the soil physical attributes (e.g. rutting, compaction, platy/massive/puddled structure) that gave the highest percent of unit disturbance, and therefore, required the most points to be sampled. 
Overall, the FSDMP gave shorter confidence intervals around the mean areal soil disturbance for each of the silvicultual prescriptions than the transect method (Table 4.2). This was due to the FSDMP requirement that a minimum of 30 points be used when sampling a cutting unit, which allows confidence intervals to be calculated from a confidence coefficient ( $\mathrm{z}$ - value) from the standard normal distribution $(\mathrm{z})$ - table. Therefore, an approximate normal distribution is achieved. In contrast, because there were only $2-4$ transects measured per unit in year 2 , confidence intervals for the transect method were obtained from the Student's t distribution table. Year 2 confidence intervals were wider than the FSDMP because, with few degrees of freedom associated with smaller sample sizes, the tabulated $\mathrm{t}$ - value was much greater than the $\mathrm{z}$ - values from the normal distribution. The $\mathrm{t}$ - distribution assumes normality, and is related to the standard normal distribution, however sample size (transect numbers vs. sample points) allowed for shorter, more precise confidence intervals to be calculated for the FSDMP. Future use of the year 2 transect method should incorporate larger sample sizes (more transects) in order to calculate more precise confidence intervals around the mean areal extent of soil disturbance. Individual transect lengths can also be shortened to keep the sampling effort the same and still produce tighter confidence intervals.

While the confidence intervals may be tighter for the FSDMP method, the mean estimates for the areal extent of site disturbance were negligible between the two methods (Table 4.2). Using the FSDMP random transect method, mean areal extent in the commercially thinned units was $0 \%$; indicating that all the disturbance class data was in class 0 . However, using the revised disturbance transect method, the areal extent of soil disturbance was $9.4 \%$ on the $0-5$ year old stands and $10.3 \%$ on the $6-10$ year old 
stands (Table 4.2). Commercial thinning resulted in the highest amount of soil disturbance in the $0-5$ and $6-10$ years since timber harvesting units. This can be attributed to one or more of the following: (1) commercially thinning ponderosa pine stands is a silvicultural prescription that produces a high level of soil disturbance, (2) the sandier soils on two of the cutting units allowed for greater amounts of visible soil disturbance, or (3) these were the first stands sampled in year 1 and the data may have been biased,. This sampling bias was also found by Miller et al. (2010); they found that experience and intensity of training were important drivers of visual classification results among observers. However, one key point that should be considered for units with a high proportion of undisturbed areas is that the distance between sample points should be reduced or the number of sample points increased when using the FSDMP. This ensures that units with high levels of class 0 disturbances will also be sampled for other disturbance types. When using the FSDMP in these stand types, low levels of soil disturbance may not happen to be in the randomly 'randomly sampled' points, and therefore it is critical to ensure that the distance between sample points is calculated so that disturbance features can be sampled. 


\section{Table 4.2}

Areal extent of soil disturbance after harvesting on the Custer National Forest, as estimated by the FSDMP and the Revised Transect sampling methods.

\begin{tabular}{ccccc}
\hline & & Length & FSDMP & Confidence \\
Prescription & Age & (m) & $\begin{array}{c}\text { Mean Areal Extent of } \\
\text { Disturbance }\end{array}$ \\
\hline Comm Thin & $0-5$ & 477 & none & $0.00 \%$ \\
Shelterwood & $0-5$ & 2608 & $6.48 \%-6.94 \%$ & $6.71 \%$ \\
Seed Tree & $0-5$ & 1105 & $2.83 \%-3.47 \%$ & $3.15 \%$ \\
Comm Thin & $6-10$ & 836 & none & $0.00 \%$ \\
Shelterwood & $6-10$ & 805 & $4.27 \%-5.09 \%$ & $4.68 \%$ \\
Seed Tree & $6-10$ & 2501 & $2.95 \%-3.71 \%$ & $3.33 \%$ \\
Control & Uncut & 772 & none & $0.00 \%$ \\
\hline & & & Transect & \\
\cline { 4 - 5 } & & Length & Confidence & Mean Areal Extent of \\
Prescription & Age & (m) & Interval & Disturbance \\
\hline Comm Thin & $0-5$ & 622 & $4.70 \%-14.06 \%$ & $9.38 \%$ \\
Shelterwood & $0-5$ & 1694 & $5.29 \%-9.63 \%$ & $7.85 \%$ \\
Seed Tree & $0-5$ & 1811 & $1.08 \%-3.98 \%$ & $2.53 \%$ \\
Comm Thin & $6-10$ & 750 & $5.15 \%-15.51 \%$ & $10.33 \%$ \\
Shelterwood & $6-10$ & 1928 & $3.58 \%-6.46 \%$ & $5.02 \%$ \\
Seed Tree & $6-10$ & 3493 & $2.24 \%-5.87 \%$ & $4.05 \%$ \\
Control & Uncut & 2453 & none & $0.00 \%$ \\
\hline
\end{tabular}

\section{Timber Harvesting}

All three harvesting prescriptions showed limited soil impact in both stand age classes, and none reached the $15 \%$ areal extent threshold for detrimental soil disturbance specified in the U.S. Forest Service Region 1 Soil Quality Guidelines (Figure 4.4 A and B). However, a statistically significant interaction was found among stand age, harvest prescription and disturbance class $(\mathrm{p}=0.0058)$ (data not shown). Overall, commercially thinned stands had higher levels of soil disturbance than the other harvest prescriptions. Commercially thinned stands $<5$ years since timber harvesting are the only stands with a statistically significant increase in Class 2 disturbance as compared to the uncut stands 
when the time since harvesting was less than 5 years (Figure $4.4 \mathrm{~A}$ ). As the time since harvesting lengthens there is a shift in data points between disturbance classes. In commercially thinned stands $\geq 6$ years since harvesting, there are statistically more data points in Class 1 compared to stands $\leq 5$ years, suggesting that some soil recovery is occurring in these stand types (Figure 4.4 B).

Commercial thinning equipment operators need to maneuver around residual trees, which can result in greater soil disturbance than shelterwood and seed tree harvests where disturbance is more concentrated on skid trails and yarding areas. The increased disturbance found with commercial thinning operations may also be a result of designated-trail spacing within these stands. In northeastern Washington, Tepp (2002) found that logging operators usually comply with 40-foot skid trail spacing during commercial thinning, but when skid trails are spaced 130-feet apart smaller supplemental skid trails were built to reach timber too far away from the original skid trail. Establishing supplemental skid trails increased the percent trail area and ultimately increased the areal extent of soil disturbance.

The smallest areal extent of disturbance occurred during seed tree harvests and reflects the type of equipment used to remove timber. Two of the three seed tree units (05 years since harvest) were cable logged (personal communication Eric Steifvater, Timber Sale Administrator, Custer National Forest ) which resulted in less soil disturbance, as compared to traditional ground-based tractor logging commonly used on the Custer National Forest. Similar results to the areal extent of disturbance were reported by Reeves et al. (In press) for ground-based vs. cable logging in a Region-1 wide study of logging operations. 

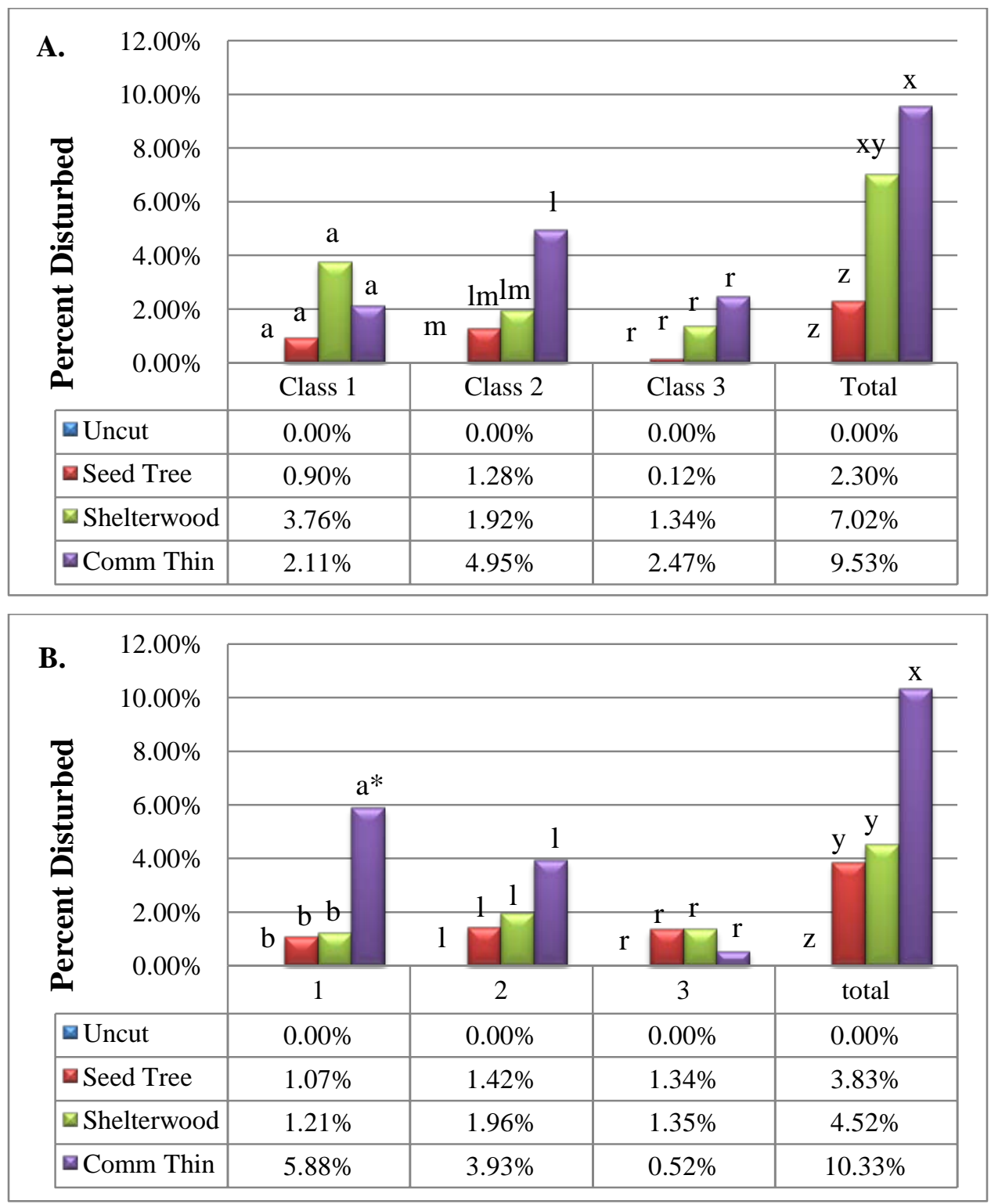

Figure 4.4. Impact of timber harvesting prescription on the areal extent of soil disturbance from year 2 transect data: A) 0-5 years since harvest, and B) 6-10 years since harvest. Letters indicate significant statistical differences between silvicultural prescriptions. $\left(^{*}\right)$ indicates statistically significant differences between age classes $(\mathrm{p}<$ $0.05)$. 


\section{Cattle Grazing and Fire}

While timber harvesting caused most of the soil disturbance across my study sites, both cattle grazing and prescribed fire were important factors in some cutting units. All soil disturbances found in the uncut control stands were from cattle activity, but they were $<1 \%$ of the areal extent of stand areas, and were in disturbance Classes 1 and 2 (Figure 4.5 A and B). Very little cattle activity was recorded in the seed tree and shelterwood harvest units $(0.13 \%$ and $0.32 \%$, respectively), and none was recorded in the commercially thinned stands. Additional disturbance resulting in higher disturbance class levels is attributed to a prescribed fire conducted in October 2007 adjacent to one of the seed tree units (6 - 10 years since harvesting) approximately 8 years after the timber sale. This fire resulted in large patches of exposed mineral soil across the entire unit (personal communication Martin Mitzkus, Fire/Recreation/Roads, Custer National Forest). In this seed tree unit large cavities developed in the mineral soil where remnant stumps and roots were completely burned out. The total area affected by fires in this stand was approximately 4\%; most disturbance was in Class \#3 (high severity burn; Figure 4.5 B). Overall, the impact of cattle activity and prescribed fire across all my

study sites was minimal, and had very little impact on total areal extent of soil disturbance in any of my stands (Figure $4.5 \mathrm{~A}$ and B). 

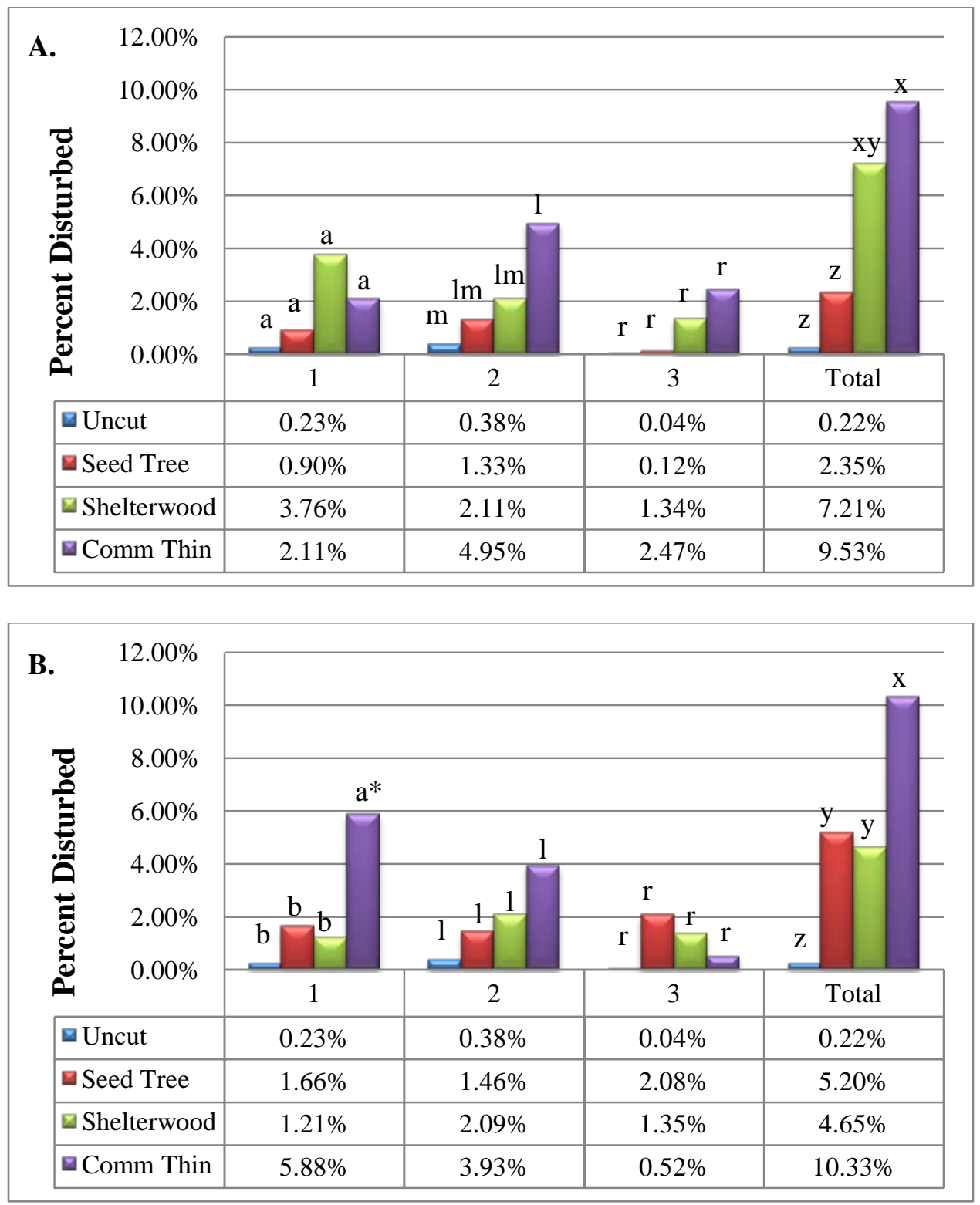

Figure 4.5. Combined areal extent of soil disturbance from timber harvesting, cattle grazing, and fire from year 2 transect data: A) 0-5 years since harvesting, and B) 6-10 years since timber harvesting. Letters indicate significant statistical differences between silvicultural prescriptions. $\left(^{*}\right)$ indicates significant differences between age classes $(\mathrm{p}<$ 0.05). 
Disturbance from cattle grazing occurred on some cutting units, but had little overall impact on soil physical properties in these upland forested stands. This result agrees with other studies on livestock distribution that show riparian areas generally receive the heaviest use, and may exhibit 7.5 times more forage utilization than adjacent uplands (Belsky and Blumenthal 1997; Gillen et al. 1984). Although, cattle can cause severe localized soil disturbances around water locations, cattle activity is less pronounced at distances $\geq 1 / 4$ mile from water sources on the Custer National Forest (personal communication Megan Dawson, Rangeland Specialist, Custer National Forest). Roath and Krueger (1982) reported cattle use in a forested range was controlled by topography, vegetation type, climate, and availability of water. Livestock dispersion was not uniform and the heaviest use was in areas where there was a lack of physical constraints to grazing. On the Custer National Forest, this dispersion was controlled by irregular topography associated with the local geology and the dryness of the climate (330 - 508 mm annual precipitation) which keeps cattle close to water locations (Hansen and Hoffman 1988).

\section{Bulk Density - Disturbance Class Relationships}

The relationship between mineral soil fine fraction bulk density and visual disturbance classes defined in the FSDMP was determined for the commercially thinned stands, since they had the highest levels of harvest-related soil disturbance (all attributes in the FSDMP). Timber harvesting disturbances were split into two categories 1) compaction and 2) all other timber disturbances (e.g. rutting, displacement, etc.). No significant statistical differences in fine fraction soil bulk density were found to exist 
between the two types of disturbance (compaction vs. all other), and the undisturbed fine fraction bulk densities. Fine fraction soil bulk density for disturbance class 3 were statistically higher than any of the other three visual disturbance classes, but disturbance classes 1 and 2 were statistically similar to undisturbed soil class 0 (Figure 4.6). Although not statistically significantly different, bulk density trends illustrate the connection between increasing disturbance class and bulk density core sampling.

For these study sites, the FSDMP soil compaction attribute for disturbance class 3 (compaction $>30 \mathrm{~cm}$ deep) was never present, but other attributes determined the class 3 disturbance level (see Appendix 1 for all attributes). Instead, rutting (> $10 \mathrm{~cm}$ deep) was the common defining attribute for disturbance class 3 in these commercially thinned stands. For Class 2 soil disturbance $>90 \%$ of data points were primarily defined by compact (10 - $30 \mathrm{~cm}$ deep) or platy structure (10 - $30 \mathrm{~cm}$ deep) (Appendix 2). Rarely, if ever, was compaction recorded present below $30 \mathrm{~cm}$, which is the depth for Class 3 compaction (Page-Dumroese et al. 2009a). For these stands, commercial thinning operations did increase bulk density to a depth of $>30 \mathrm{~cm}$ (Class 3), but rutting ( $>10 \mathrm{~cm}$ deep) caused by timber harvesting equipment was considered the attribute that might impact long-term productivity the greatest by altering the surface hydrology. Soil cores taken to verify bulk density changes and its relationship to disturbance class did not exceed an increase of $15 \%$ needed to be considered detrimental disturbance, as specified in the Region 1 Soil Quality Guidelines (USDA Forest Service 1991) in this study.

Williamson and Neilsen (2000) report that, on average, $62 \%$ of compaction in the surface $10 \mathrm{~cm}$ occurs following a single pass of load bearing logging machinery and by 
the third pass $80-95 \%$ of the final compaction value was attained in the $10-20$ and 20 - $30 \mathrm{~cm}$ soil layers on two fine-textured soils (sandy clay loam and loam - silt loam silty clay). Furthermore, both Williamson and Neilsen (2000) and Cullen et al. (1991) reported no differences in bulk density below $30 \mathrm{~cm}$ following timber harvesting activities under dry forest soil conditions. The results of my study agree with these two previous studies suggesting that compaction does occur from minimum amounts of machine passes associated with commercial thinning operations, but the depth of compaction rarely exceeds $30 \mathrm{~cm}$ because of dissipated forces insufficient to impact soil physical properties under dry soil conditions often associated with the Custer National Forest (308 - $508 \mathrm{~mm}$ annual precipitation).

Stands monitored a relatively short time ( 0 - 5 years) following commercial thinning operations had the greatest areal extent of soil disturbance from rutting in the disturbance class 3 category (Figure 4.4). This result is most likely a combination of two factors 1) texture and 2) equipment. Commercially thinned treatments had statistically lower amounts of percent fines in this study (highest percent sand). Tire rotations produce shearing forces that loosen the soil, and dry sandy soils lack cohesion (Vossbrink and Horn 2004; Ampoorter et al. 2007), so the increased equipment turns associated with leaving residual timber combined with loose soils could be the reason for the increased rutting in these stands. 


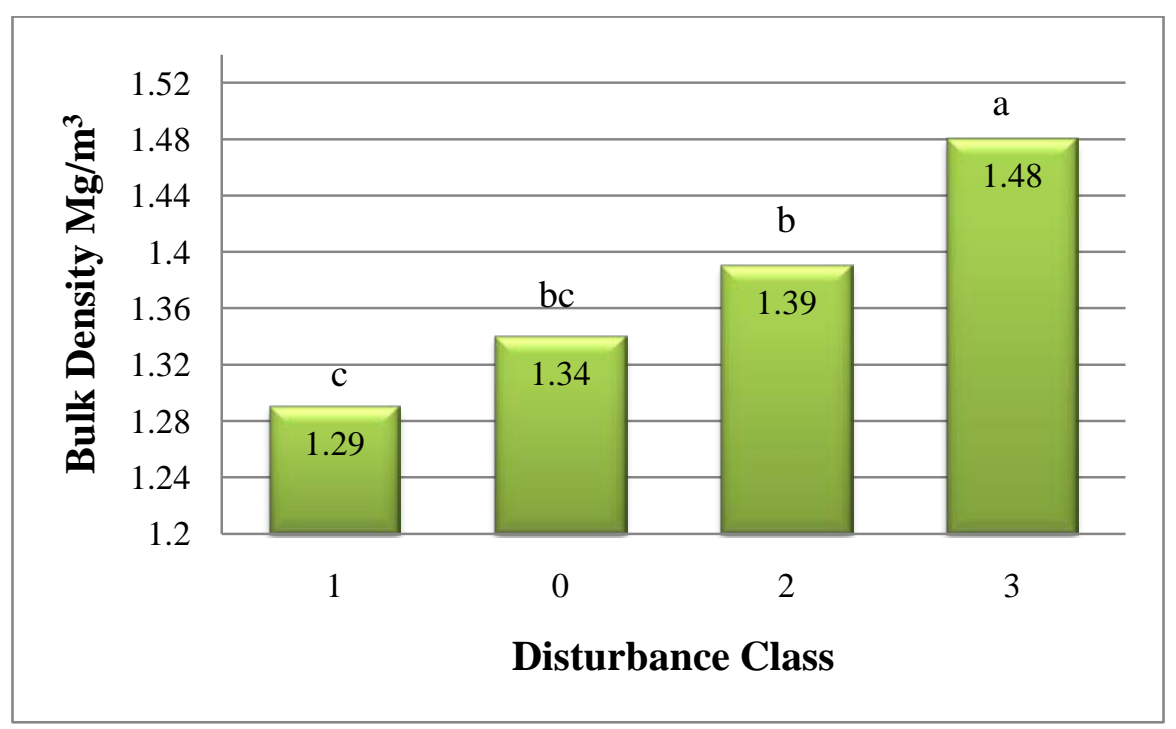

Figure 4.6. Fine fraction bulk density values and their associated FSDMP visual disturbance class from both years' data for the commercial thinning silvicultural prescription only. Different letters among disturbance classes indicates statistically significant differences $(\mathrm{p}<0.05)$.

\section{MANAGEMENT IMPLICATIONS}

The FSDMP provides a rapid assessment for both pre - and post-land management activity soil disturbance, and uses visual soil attributes and physical property changes to determine the kinds of disturbance, the distribution of disturbance across the harvest unit, and provides an indication of harvest impact severity. While the data collected using the FSDMP did detect soil disturbances associated with timber harvesting on the Custer National Forest, it did not detect all soil disturbance within the harvest unit, and when continuous transects were used to locate disturbance, finding Class 2 and 3 disturbances proved to be more successful for describing the full extent of disturbance within a harvest unit. The transect method provided accurate and comparable estimates of mean areal unit disturbance to that of FSDMP. Accurate monitoring data 
that identifies the attributes responsible for altering the level of soil disturbance is important for meeting current soil quality standards in the U.S. Forest Service. Accurate monitoring also helps land mangers understand changes in soil physical properties that could potentially alter soil quality and reduce long-term site productivity.

Commercial thinning activities on the Custer National Forest caused the largest amount of soil disturbance, but ground-based timber harvesting activities on the Custer National Forest are not causing large amounts of soil disturbances, and none of the units sampled reached the $15 \%$ threshold for areal extent of detrimental disturbance outlined by the Region 1 Soil Quality Guidelines (USDA Forest Service 1991) as the threshold of maximum soil disturbance. This analysis of harvest-caused disturbance on the Custer National Forest resulted in a similar outcome as the Region 1-wide study conducted by Reeves et al. (In press) in which only legacy data was used.

The FSDMP visual disturbance class 3 (most severe) had a significantly higher bulk density than any of the other three visual disturbance classes (0 - none, 1, and 2). While the increase in bulk density is less than the Region 1 threshold of a $15 \%$ increase above the natural bulk density to be considered "detrimental disturbance”, the change in bulk density was still statistically significant. This suggests that using a percent increase to define detrimental soil conditions across a wide variety of soils within the region may not be an accurate measure when determining the impacts of management activities due to site specific soil - plant interactions. 
My study indicates that both the FSDMP method and the transect method can be used by managers, specialists, or technicians to attain accurate estimates of percent soil disturbance within a harvest unit. However, the FSDMP appears not to be as good of a predictor of areal extent of soil disturbance as the transect method in units that do not have much disturbance present. Furthermore, bulk density values for each of the FSDMP visual disturbance class estimates appear to suggest that they are defined accurately, and that as the severity of the visual disturbance increases (e.g. 2 - 3), so does the impact to the mineral soil. 


\section{REFERENCES}

Adams WA. 1973. The effect of organic matter on the bulk and true densities of some uncultivated podzolic soils. Journal of Soil Science. 24:10-17.

American Society for Testing and Materials. 1985. Standard test method for particlesize analysis of soils. D 422 - 63 (1972). 1985 annual book of ATSM standards. 04(08):117-127. American Society for Testing and Materials, Philadelphia, PA.

Ampoorter E, Goris R, Cornelis WM, Verheyen K. 2007. Impact of mechanized logging on compaction status of sandy forest soils. Forest Ecology and Management. 241:167-174.

Andraski BJ. 1991. Balloon and core sampling for determining bulk density of alluvial desert soil. Soil Science Society of America Journal. 55:1188-1190.

Belsky AJ, Blumenthal DM. 1997. Effects of livestock grazing on stand dynamics and soils in upland forests of the interior west. Conservation Biology. 11:315-327.

Bock MD, VanRees KCJ. 2002. Mechanical site preparation impacts on soil properties and vegetation communities in the Northwest Territories. Canadian Journal of Forest Research. 32:1381-1392.

Burger JA. 1997. Conceptual framework for monitoring the impacts the impacts of intensive forest management on sustainable forestry. In: Hakkila P, Heino M, Puranen E. (Eds.). Forest Management for Bio-energy. The Finnish Forest Research Institute. Research Papers. 640:147-156

Burger JA, Gray G, Scott DA. 2010. Using Soil Quality Indicators for Monitoring Sustainable Forest Management. In: Page-Dumroese D, Neary D, Trettin C. tech. eds. 2010. Scientific background for soil monitoring on National Forests and Rangelands: workshop proceedings; April 29-30, 2008; Denver, CO. Proc. RMRS-P59. Fort Collins, CO: U.S. Department of Agriculture, Forest Service, Rocky Mountain Research Station. 127 p.

Busse MD. 1994. Downed bole-wood decomposition in lodgepole pine forests of central Oregon. Soil Science Society of America Journal. 58:221-227.

Clayden B, Hollis JM. 1984. Criteria for differentiating soil series. Tech. Monograph, vol. 17. Soil Survey and Land Research Center, Sisloe, UK.

Cullen SJ, Montagne C, Ferguson H. 1991. Timber harvest trafficking and compaction in western Montana. Soil Science Society of America Journal 55:1416-1421. 
Curran MP, Miller RE, Howes SW, Maynard DG, Terry TA, Heninger RL, Niemann T, Van Rees K, Powers RF, Schoenholtz SH. 2005. Progress towards more uniform assessment and reporting of soil disturbance for operations, research, and sustainability protocols. Forest Ecology and Management. 220:17-30.

Davis RL, Sanchez F, DeHart S. 2010. Soil quality standards monitoring program administration and implementation. In: Page-Dumroese D, Neary D, Trettin C. tech. eds. 2010. Scientific background for soil monitoring on National Forests and Rangelands: workshop proceedings; April 29-30, 2008; Denver, CO. Proc. RMRS-P59. Fort Collins, CO: U.S. Department of Agriculture, Forest Service, Rocky Mountain Research Station. 127 p.

DeLuca TH, Archer V. 2009. Forest soil quality standards should be quantifiable. Journal of Soil and Water Conservation. 64(4):117A-123A.

Dexter AR. 2004. Soil physical quality Part I. Theory, effects of soil texture, density, and organic matter, and effects on root growth. Geoderma. 120: 201-214.

Federer CA, Turcotte DE, Smith CT. 1993. The organic fraction - bulk density relationship and the expression of nutrient content in forest soils. Canadian Journal of Forest Research. 23:1026-1032.

Froelich HA, Miles DWR, Robbins RW. 1986. Growth of young Pinus ponderosa and Pinus contorta on compacted soil in Central Washington. Forest Ecology and Management. 15:285-294.

Gillen RL, Krueger WC, Miller RF. 1984. Cattle distribution on mountain rangeland in northeastern Oregon. Journal of Range Management. 37:549-553.

Gomez AG, Powers RF, Singer MJ, Horwath WR. 2002. N uptake and N status in ponderosa pine as affected by soil compaction and forest floor removal. Plant Soil. 242:263-275.

Greacen EL, Sands R. 1980. Compaction of forest soils. A review. Australian Journal of Soil Research. 18:163-189.

Hansen RL, Hoffman GR. 1988. The vegetation of the Grand River/Cedar River, Sioux, and Ashland Districts of the Custer National Forest: A habitat classification. General Technical. Report. RM-157. U.S. Department of Agriculture, Forest Service, Rocky Mountain Forest and Range Experimental Station. Fort Collins, CO.

Harr RD, Fredriksen RL, Rothatcher J. 1979. Changes in streamflow following timber harvest in southwest Oregon. U.S. Department of Agriculture, Forest Service. Research. Paper PNW - 24. Pacific Northwest Forest and Range Experimental Station. Portland, OR. 
Hatchell GE, Ralson CW, Foil RR. 1970. Soil disturbance in logging. Journal of Forestry. 68:772-775.

Helms JA, Hipkin C. 1986. Effects of soil compaction on tree volume in a California ponderosa pine plantation. Western Journal of Applied Forestry. 1:121-124.

Heninger R, Scott W, Dobkowski A, Miller R, Anderson H, Duke S. 2002. Soil disturbance and 10 year growth response of coast Douglas-fir on nontilled and tilled skid trails in the Oregon Cascades. Canadian Journal of Forest Resources. 32:233246

Howard RF, Singer MJ, Frantz GA. 1981. Effects of soil properties, water content, and compaction of selected California forest and range soils. Soil Science Society of America Journal. 45:231-236.

Howes SJ, Hazard J, Geist MJ. 1983. Guidelines for sampling some physical conditions of surface soils. R6-PNW-146. U.S. Department of Agriculture, Forest Service, Pacific Northwest Region Publication. 34p.

Johnson LR, Page-Dumroese D, Han HS. 2007. Effects of machine traffic on the physical properties of ash-cap soils. In: Page-Dumroese D, Miller R, Mital J, McDaniel P, Miller D. tech. eds. 2007. Volcanic-ash-derived forest soils of the Inland Northwest: Properties and implications for management and restoration. Workshop proceedings; November 9 -10, 2005; Coeur d'Alene, ID. Proc. RMRS-P44. Fort Collins, CO: U.S. Department of Agriculture, Forest Service, Rocky Mountain Research Station.

Kabzems R, Haeussler S. 2005. Soil properties, aspen, and white spruce responses 5 years after organic matter removal and compaction treatments. Canadian Journal of Forest Research. 35:2045-2055.

Kozlowski TT. 1999. Soil compaction and growth of woody plants. Scandinavian Journal of Forest Research. 14:(6)596-619.

Miller RE, McIver JD, Howes SW, Gaeuman WB. 2010. Assessment of soil disturbance in forests of the Interior Columbia River Basin. General Technical Report PNWGTR-811. U.S. Department of Agriculture, Forest Service, Pacific Northwest Research Station. Portland, OR. 140 p.

Miller RE, Scott W, Hazard JW. 1996. Soil compaction and conifer growth after tractor yarding at three coastal Washington locations. Canadian Journal of Forest Research. 26:225-236. 
Morris LA, Miller RE. 1994. Evidence for long-term productivity changes as provided by field trials. In: Dyck WJ, Cole DW, Cornerfield NB. Impacts of forest harvesting on long-term site productivity. Chapman and Hall, London. pp. 41-80

Murphy G. 1982. Soil damage associated with production thinning. New Zealand Journal of Forestry. 12:281-292.

Neary DG, Page-Dumroese D, Trettin CC. 2010. Soil quality monitoring: examples of existing protocols. In: Page-Dumroese D, Neary D, Trettin C. tech. eds. 2010. Scientific background for soil monitoring on National Forests and Rangelands: workshop proceedings; April 29-30, 2008; Denver, CO. Proc. RMRS-P-59. Fort Collins, CO: U.S. Department of Agriculture, Forest Service, Rocky Mountain Research Station. 127 p.

Page-Dumroese DS, Abbott AM, Rice TM. 2009a. Forest Soil Disturbance Monitoring Protocol: Volume I: Rapid assessment. U.S. Department of Agriculture, Forest Service. General Technical Report. WO-GTR-82a. Washington, DC. 31 p.

Page-Dumroese DS, Abbott AM, Rice TM. 2009b. Forest Soil Disturbance Monitoring Protocol: Volume II: Supplementary methods, statistics, and data collection. U.S. Department of Agriculture, Forest Service. General Technical Report. WO-GTR82b. Washington, DC. $64 \mathrm{p}$.

Page-Dumroese DS, Jurgensen MF, Brown RE, Mroz, GD. 1999. Comparison of methods for determining bulk density of rocky forest soils. Soil Science Society of America Journal. 63:379-383.

Page-Dumroese D, Jurgensen M, Elliot W, Rice T, Nesser J, Collins T, Meurisse R. 2000. Soil quality standards and guidelines for forest sustainability in the northwestern North America. Forest Ecology and Management. 138:445-462.

Page-Dumroese DS, Jurgensen MF, Tiarks AE, Ponder Jr. FP, Sanchez FG, Fleming RL, Krananbetter JM, Powers RF, Stone DM, Elioff JD, Scott DA. 2006. Soil physical property changes at the North American Long-Term Soil Productivity study sites: 1 and 5 years after compaction. Canadian Journal of Forest Research. 36:551-564.

Powers RF. 1991. Are we maintaining the productivity of forest lands? Establishing guidelines through a network of long-term studies. In: Harvey A E, Neuenschwander L F. Management and productivity of western-montane forest soils: workshop proceedings; April 10-12, 1990; Boise, Idaho. USDA Forest Service General Technical Report. INT-GTR-280. pp 70-89. 
Powers RF, Myers RK. 1989. The maintenance or improvement of farming systems in North America and Australia. In: Stewart J B. (Ed.). Soil quality in semi-arid agriculture. Proc. of an Int. Conf. Sponsored by the Canadian Int. Development Agency, 11-16 June 1989. Saskatchewan, Canada. Saskatchewan Institute of Pedology. Saskatoon, Saskatchewan, Canada. pp. 273-292.

Powers RF, Tiarks AE, Boyle JR. 1998. Assessing soil quality: practicable standards for sustainable forest productivity in the United States. In: Davidson EA, Adams MB, Ramakrishna K. (Eds.). The contribution of soil science to the development and implementation of criteria and indicators of sustainable forest management. Soil Science Society of America Special Publication. No. 53: 53-80. SSSA, Madison, WI.

Reisinger TW, Simmons GL. 1988. The impact of timber harvesting on soil properties and seedling growth in the south. Southern Journal of Applied Forestry. 12(1): 58 67.

Reeves D, Page-Dumroese D, Coleman M. In press. Detrimental soil disturbance associated with timber harvest systems on National Forests in the Northern Region. Research Paper RMRS-RP-\#\#. Fort Collins, CO: U.S. Department of Agriculture, Forest Service, Rocky Mountain Research Station. 30 p.

Roath LR, Krueger WC. 1982. Cattle grazing behavior on a forested range. Journal of Range Management. 35:332-338.

Sample AV, Kavanough SL, Snieckus MM (eds.). 2006. Advancing sustainable forest management in the United States. Pinchot Institute for Conservation. Washington, DC.

Santisteban JI, Mediavilla R, Lopez-Pamo E, Dabrio CJ, Zapata MBR, Garcia MJG, Castano S, Martinez-Alfaro PE. 2004. Loss on ignition: a qualitative or quantitative method for organic matter and carbonate mineral content in sediments? Journal of Paleolimnology. 32:287-299.

Siegel-Issem CM, Burger JA, Powers RF, Ponder F, Patterson SC. 2005. Seedling root growth as a function of soil density and water content. Soil Science Society of America Journal. 69:215-226.

Soane BD. 1990. The role of organic matter in soil compactibility: A review of some practical aspects. Soil and Tillage Research. 16:179-201.

Spears JH, Holub SM, Harmon ME, Lajith K. 2003. The influence of decomposing logs on soil biology and nutrient cycling in an old-growth mixed coniferous forest in Oregon, U.S.A. Canadian Journal of Forest Research. 33:2193-2201. 
Steber A, Brooks K, Perry CH, Kolka R. 2007. Surface compaction estimates and soil sensitivity in aspen stands of the Great Lake States. Northern Journal of Applied Forestry. 24(4):276-281.

Tepp JS. 2002. Assessing visual soil disturbance on eight commercially thinned sites in northeastern Washington. U.S. Department of Agriculture, Forest Service. Research Note PNW-RN-535. Pacific Northwest Research Station, Wenatchee, WA. 15p.

USDA Forest Service. 1991. Soil management handbook, soil quality monitoring. FSH 2509.18 Chapter 2. WO Amendment 2509.18-91-1. Effective 9/3/91. U.S. Department of Agriculture, Forest Service. Washington D.C.

USDA Soil Conservation Service. 1971. Soil Survey of Powder River Area, Montana. USDA Soil Conservation Service and Forest Service, USDI Bureau of Land Management, and Montana Agricultural Experiment Station. U.S. Gov. Print. Office, Washington, DC. Available on the world wide web from http://websoilsurvey.nrcs.usda.gov/app/.

Vossbrink J, Horn R. 2004. Modern forestry vehicles and their impact on soil physical properties. European Journal of Forest Research. 123:259-267.

Williamson JR, Neilsen WA. 2000. The influence of forest site on rate and extent of soil compaction and profile disturbance of skid trails during ground-based harvesting. Canadian Journal of Forest Research. 30:1196-1205.

Worell R, Hampson A. 1997. The influence of some forest operations on the sustainable management of forest soils - A Review. Journal of Forestry. 70(1):62-75. 


\section{Appendix 1}

\section{Table 7.1}

Abbreviated FSDMP soil attribute monitoring form. Except for forest floor depth, 1's (present) or 0’s (absent) are used to indicate soil cover and impacts to the mineral soil.

\begin{tabular}{|c|c|c|c|c|c|c|c|}
\hline Project ID: & & & & & & & 0 \\
\hline Date: & & & & Monitoring Type: & & & \\
\hline Direction: & & & & & & & \\
\hline Sample point & 1 & 2 & 3 & 4 & 5 & 6 & 7 \\
\hline f. floor depth $(\mathrm{cm})$ : & & & & & & & \\
\hline Forest floor Impacted? & & & & & & & \\
\hline & & & & & & & \\
\hline Live Plant? & & & & & & & \\
\hline Invasive Plant? & & & & & & & \\
\hline Fine Woody? $<7 \mathrm{~cm}$ & & & & & & & \\
\hline Coarse Woody? >7cm & & & & & & & \\
\hline Bare Soil? & & & & & & & \\
\hline Rock? & & & & & & & \\
\hline & & & & & & & \\
\hline Topsoil displacement? & & & & & & & \\
\hline Erosion?, comment! & & & & & & & \\
\hline Rutting? $<5 \mathrm{~cm}$ & & & & & & & \\
\hline Rutting? $5-10 \mathrm{~cm}$ & & & & & & & \\
\hline Rutting? $>10 \mathrm{~cm}$ & & & & & & & \\
\hline Burning light & & & & & & & \\
\hline Burning moderate & & & & & & & \\
\hline Burning severe & & & & & & & \\
\hline Compaction? 0-10 cm & & & & & & & \\
\hline Compaction? $10-30 \mathrm{~cm}$ & & & & & & & \\
\hline Compaction? $>30 \mathrm{~cm}$ & & & & & & & \\
\hline $\begin{array}{l}\text { Platy/Massive/Puddled } \\
\text { structure } 0-10 \mathrm{~cm}\end{array}$ & & & & & & & \\
\hline $\begin{array}{l}\text { Platy/Massive/Puddled } \\
\text { structure } 10-30 \mathrm{~cm}\end{array}$ & & & & & & & \\
\hline $\begin{array}{l}\text { Platy/Massive/Puddled } \\
\text { structure }>30 \mathrm{~cm}\end{array}$ & & & & & & & \\
\hline & & & & & & & \\
\hline N Needed (round UP) & & & & & & & \\
\hline INVALID! $<30$ & & & & & & & \\
\hline Soil Disturbance Class & & & 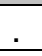 & . & . & . & \\
\hline Detrimental Disturbance & & & & & & & \\
\hline Comments & & & & & & & \\
\hline
\end{tabular}




\section{APPENDIX 2}

\section{Table 8.1}

Total number of timber harvesting related disturbances per FSDMP disturbance class for prescriptions 0 - 5 years combined with represented soil series.

\begin{tabular}{|c|c|c|c|c|c|c|c|c|c|}
\hline \multirow[b]{3}{*}{ Prescription } & \multirow[b]{3}{*}{ Age } & \multirow[b]{3}{*}{ Soil Series } & \multirow[b]{3}{*}{ Texture } & \multirow{2}{*}{\multicolumn{3}{|c|}{ Compaction - Massive/Platy }} & \multirow{2}{*}{\multicolumn{3}{|c|}{ Rutting or Displacement }} \\
\hline & & & & & & & & & \\
\hline & & & & Class 1 & Class 2 & Class 3 & Class 1 & Class 2 & Class 3 \\
\hline \multirow[t]{4}{*}{ Comm Thin } & $0-5$ & Cabba & Silt Loam & 0 & 5 & 0 & 1 & 2 & 3 \\
\hline & & Midway & Clay Loam & & & & & & \\
\hline & & & Sandy Clay & & & & & & \\
\hline & & Heldt & Loam & & & & & & \\
\hline \multirow[t]{4}{*}{ Seed Tree } & $0-5$ & Cabba & Silt Loam & 2 & 5 & 0 & 1 & 0 & 1 \\
\hline & & Midway & Clay Loam & & & & & & \\
\hline & & Farland & Silt Loam & & & & & & \\
\hline & & Elso & Silt Loam & & & & & & \\
\hline \multirow[t]{5}{*}{ Shelterwood } & $0-5$ & Cabba & Silt Loam & 7 & 13 & 2 & 6 & 0 & 2 \\
\hline & & Farland & Silt Loam & & & & & & \\
\hline & & & Sandy Clay & & & & & & \\
\hline & & Heldt & Loam & & & & & & \\
\hline & & Havrelon & Silt Loam & & & & & & \\
\hline
\end{tabular}




\section{APPENDIX 3}

Table 9.1

Total number of timber harvesting related disturbances per FSDMP disturbance class for prescriptions 0 - 5 years combined with represented soil series.

\begin{tabular}{|c|c|c|c|c|c|c|c|c|c|}
\hline \multirow[b]{3}{*}{ Prescription } & \multirow[b]{3}{*}{ Age } & \multirow[b]{3}{*}{ Soil Series } & \multirow[b]{3}{*}{ Texture } & \multirow{2}{*}{\multicolumn{3}{|c|}{ Compaction - Massive/Platy }} & & & \\
\hline & & & & & & & \multicolumn{3}{|c|}{ Rutting or Displacement } \\
\hline & & & & Class 1 & Class 2 & Class 3 & Class 1 & Class 2 & Class 3 \\
\hline \multirow[t]{5}{*}{ Comm Thin } & $6-10$ & Cabba & Silt Loam & 4 & 5 & 0 & 2 & 0 & 1 \\
\hline & & Farland & Silt Loam & & & & & & \\
\hline & & Havrelon & Silt Loam & & & & & & \\
\hline & & Campspass & Loam & & & & & & \\
\hline & & Barvon & Loam & & & & & & \\
\hline \multirow[t]{4}{*}{ Seed Tree } & $6-10$ & Cabba & Silt Loam & 3 & 3 & 0 & 3 & 4 & 3 \\
\hline & & Farland & Silt Loam & & & & & & \\
\hline & & Havrelon & Silt Loam & & & & & & \\
\hline & & Rapelje & Silt Loam & & & & & & \\
\hline \multirow[t]{4}{*}{ Shelterwood } & $6-10$ & Cabba & Silt Loam & 4 & 7 & 5 & 4 & 0 & 0 \\
\hline & & Campspass & Silt Loam & & & & & & \\
\hline & & Midway & Clay Loam & & & & & & \\
\hline & & Barvon & Loam & & & & & & \\
\hline
\end{tabular}

